\title{
The Role of Law in Assessing the Value of Transparency and the Disconnect with the Lived Realities under Investor-State Dispute Settlement
}

\author{
Dr Fola Adeleke \\ Senior Researcher, Mandela Institute \\ University of Witwatersrand, Johannesburg \\ +27 (0) 11717 8447, Fola.Adeleke@wits.ac.za
}

Transparency is often uncritically considered a pre-requisite to accountability within the ISDS system, without much discussion directed to how transparency is instrumental to achieving such accountability. Yet, transparency is generally thought to be the golden bullet for effecting social transformation as well as considerations of the public interest in investor state dispute settlement (ISDS). This article aims at fostering deeper and more critical debate on the notion of transparency; in order to better understand both the ways in which it could be conceived for the purposes of transformation of the ISDS system and the extent to which international investment law and global administrative law (GAL), is a useful concept for this purpose. This paper considers the ways in which the legislative and policy framework governing transparency creates the conditions whereby state and investors utilize the language and practice of transparency as a self-legitimising tool through its claim to accountability. This is further tested against choices made by state institutions and the ISDS system itself for the alluring concept of voluntary disclosures with no enforcement mechanisms-an intellectual contradiction. In response to this quandary, this paper aims at addressing some of the theoretical gaps identified above, particularly by examining the conceptual understandings of transparency, the current state of transparency in the ISDS system and the role of GAL in revamping the system.

Research for this paper was funded by the Swiss State Secretariat for Economic Affairs under the SECO / WTI Academic Cooperation Project, based at the World Trade Institute of the University of Bern, Switzerland.

SECO working papers are preliminary documents posted on the WTI website (www.wti.org) and widely circulated to stimulate discussion and critical comment. These papers have not been formally edited. Citations should refer to a "SECO / WTI Academic Cooperation Project" paper with appropriate reference made to the author(s).

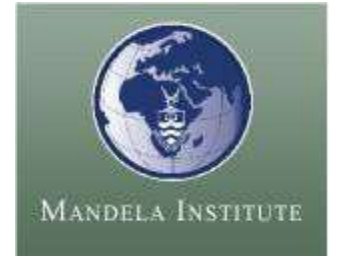


THE ROLE OF LAW IN ASSESSING THE VALUE OF TRANSPARENCY AND THE DISCONNECT WITH THE LIVED REALITIES UNDER INVESTOR-STATE DISPUTE SETTLEMENT

Transparency is often uncritically considered a pre-requisite to accountability within the ISDS system, without much discussion directed to how transparency is instrumental to achieving such accountability. Yet, transparency is generally thought to be the golden bullet for effecting social transformation as well as considerations of the public interest in investor state dispute settlement (ISDS). This article aims at fostering deeper and more critical debate on the notion of transparency; in order to better understand both the ways in which it could be conceived for the purposes of transformation of the ISDS system and the extent to which international investment law and global administrative law (GAL), is a useful concept for this purpose. This paper considers the ways in which the legislative and policy framework governing transparency creates the conditions whereby state and investors utilize the language and practice of transparency as a selflegitimising tool through its claim to accountability. This is further tested against choices made by state institutions and the ISDS system itself for the alluring concept of voluntary disclosures with no enforcement mechanisms-an intellectual contradiction. In response to this quandary, this paper aims at addressing some of the theoretical gaps identified above, particularly by examining the conceptual understandings of transparency, the current state of transparency in the ISDS system and the role of GAL in revamping the system.

\footnotetext{
* Fola Adeleke, Mandela Institute, University of Witwatersrand. This article forms part of my $\mathrm{PhD}$ in the School of Law, University of the Witwatersrand. I am grateful to Prof. Klaaren and the numerous anonymous reviewers for their comments. A part of this article was presented at the Law \& Society Conference, Seattle May 2015. I am grateful to the World Trade Institute for their financial support.
} 


\section{INTRODUCTION}

Investment disputes are resolved under various international bodies which apply different rules. ${ }^{1}$ These rules were created in order to resolve disputes between parties about contractual matters using the principles of commercial arbitration with modifications due to one party being a public entity. ${ }^{2}$ The process is driven by the parties who can appoint the arbitrators and agree on the applicable law. ${ }^{3}$ ISDS is often the subject of much criticism regarding the legitimacy of the system, pro-investor bias, broad investor rights and conflicting interpretation of these rights. This cumulatively brings the suitability of the arbitration system into question especially when the scope of state powers and public interest is at stake. ${ }^{4}$ As a result, some states have withdrawn from investment treaties because of these problems. ${ }^{5}$ Various solutions have been proffered to address these problems with transparency occupying a prominent position. In recent times, there have been significant advances in the application of transparency measures in ISDS. These developments are good and welcome. In this article, I will discuss the current state of transparency measures and the recent advances. I will argue that the recent advances in transparency would be enriched through the global administrative law (GAL) approach and that the GAL approach would allow for further advances.

The call for transparency in the ISDS process has dominated the debate of academics and policy makers. In contributing to this debate, the questions I hope to answer in this article in terms of the further advances that the GAL approach can introduce into the current state of transparency are what kind of transparency is needed for the ISDS regime, at what level should transparency be infused into the ISDS process, is transparency the same as information disclosure? If so, who should disclose information, what kind of information should be disclosed, in what manner should the information be disclosed, who should be the recipients of the information? These

\footnotetext{
${ }^{1}$ These rules include UNCITRAL, ICSID, Rules of the Stockholm Chamber of Commerce, International Chamber of Commerce, Permanent Court of Arbitration and London Court of International Arbitration.

${ }^{2} \mathrm{~S}$ Schill 'Crafting the international economic order: the public function of investment treaty arbitration and its significance for the role of the arbitrator' (2010) 23(2) LJIL 401402.

${ }^{3}$ Ibid.

${ }^{4}$ Ibid.

${ }^{5}$ Both Bolivia and Ecuador have withdrawn from the ICSID Convention.
} 
considerations are significant and expected to shape the discourse regarding public interest considerations in ISDS through the application of GAL.

\section{CONCEPTUAL UNDERSTANDINGS OF TRANSPARENCY}

The notion of transparency as a means of improving ISDS to ensure greater legitimacy and credibility of the process is one of the outcomes of GAL to ensure accountability of global governance institutions to the broader public. The various debates in favour of transparency and the measures to improve the system through new rules of transparency that are being adopted by various investment dispute bodies all point to the undeniable fact that transparency is recognised as a measure that improves ISDS as a tool for good governance and should not be resisted. ${ }^{6}$ What the notion of transparency means has been explored in various studies and in this article, I evaluate the various forms with the objective of identifying a suitable transparency framework that can serve as a model for various dispute resolution bodies in the context of ISDS.

Transparency is becoming a field of knowledge on its own and the genesis of transparency is often traced to the work on information asymmetries which stated that the supply and demand of information was necessary for the efficiency of markets. ${ }^{7}$ With the political and economic changes globally, transparency began to find a new meaning and globalisation as well as technology began to erode secrecy as an ideology in the mid-1990s. ${ }^{8}$ Globalisation, transnational forms of governance and the growth of information and communication technologies (ICTs) are some of the drivers of transparency. ${ }^{9}$

Chayes and Chayes define transparency as the availability and accessibility of knowledge and information about the meaning of norms, rules, and procedures established by the treaty and practice of the regime, and the policies and activities of parties to the treaty and of any central organs of the regime as to matters relevant to treaty compliance and regime efficacy. ${ }^{10}$ Zoellner argues that it is apparent then that transparency requires accessibility and clarity not only with regard to a legal regime's

\footnotetext{
6 The ICSID adopted amendments in 2006 dealing with better transparency measures while the UNCITRAL rules are undergoing a process of review for improved transparency measures.

${ }^{7}$ G Michener and K Bersch 'Conceptualising the Quality of Transparency' Paper prepared for the 1st Global Conference on Transparency Rutgers University, Newark, May 17-20 20113.

${ }^{8}$ Michener and Bersch (note 7) 4.

${ }^{9}$ M Flyverbom, L Christensen, H Hansen 'Disentangling the Power-Transparency Nexus' Paper prepared for the 1st Global Conference on Transparency Rutgers University, Newark, May 17-20 20114.

${ }^{10}$ A Chayes \& A H Chayes The New Sovereignty (1995) 135-53.
} 
treaty obligations but also to the actions of relevant parties which could impair benefits flowing from the provisions in question or otherwise impact the scope and operation of the system. ${ }^{11}$ This definition suggests the application of transparency to the dissemination of information by both the tribunal relating to procedure and reasons in a dispute, and the parties relating to their pleadings. It also distinguishes transparency from public participation and does not designate transparency obligations to a single role player within the arbitration system. These are significant issues that are explored later in this article.

Hood noted that there are two strains of transparency. According to him, direct transparency is the more populist definition through which 'information is released through direct observation or direct interaction between administrators and citizens. ${ }^{12}$ Indirect transparency is more technocratic and refers to the fact that some information and its reporting 'makes activity or results visible or verifiable...only to agents or technical experts'. ${ }^{13}$ While direct transparency allows citizens to receive information, indirect transparency limits accessibility to experts as the primary recipients of information.

Zoellner identifies three concepts of transparency under international law. These include concepts underlying obligations international law places on a state's internal legal regimes and procedures; overseeing the relations between institutions and regimes of international law and member states; and as a concept denoting the openness of institutions and procedures of international law, especially concerning international civil society. ${ }^{14}$ For the purposes of ISDS, this article mainly adopts the concept of transparency in the third sense. The first concept however is also applicable and explored in the context of the obligations of states and their access to information laws and the extent of compatibility of this obligation with international law obligations imposed on states. The second concept is also discussed in the context of the political underplay between parties and the push for transparency in arbitration for different motives. In the third sense, within the investment regime various players are present. On the one side are parties to the disputes and civil society whose concern relate to broad

\footnotetext{
${ }^{11} \mathrm{C}$ Zoellner 'Transparency: An analysis of an evolving fundamental principle in international economic law' (year) 27 Michigan J Int Law 5793.

${ }^{12}$ C Hood 'What Happens When Transparency Meets Blame-Avoidance' (2007) 9 Public Management Review, 191-210.

${ }^{13}$ Hood (note 12 above) 194.

${ }^{14}$ Zoellner (note 11 above) at 2.
} 
public interest issues while on the other side are the players who include the members of the arbitration panel and treaty drafters who use their ability to influence the development of the investment regime. The relations between these players within the investment regime are crucial and also discussed.

Transparency has been explored in various forms. Hood explores it as a doctrine of 'good governance, ${ }^{, 15}$ while it has also been explored as the 'power of information'. 16 In whatever light transparency has been explored, transparency has often been seen as a solution to problems that flourish under the shroud of secrecy, it is a powerful concept often invoked as the all-encompassing solution to demands of accountability.

Rawlins defines transparency as 'the deliberate attempt to make available all legally releasable information, whether positive or negative in nature, in a manner that is accurate, timely, balanced and unequivocal, for the purpose of enhancing the reasoning ability of the public and holding organisations accountable for their actions, policies, and practices. ${ }^{17}$ Following this definition, Rawlins urges organisations to voluntarily 'share information that is inclusive, auditable (verifiable), complete, relevant, accurate, neutral, comparable, clear, timely, accessible, reliable, honest, and holds the organisation accountable. ${ }^{18}$

Rawlins definition is different from Chayes definition above. Chayes' definition separates transparency from concepts of accountability and separating the two discounts motives behind the push for transparency by a particular party. The supply of information by an entity and the demand of information all relates to the strengthening of the positions of role players in terms of control in a given situation. ${ }^{19}$

Transparency is assessed in terms of its clarity and accuracy. For these conditions to exist, a demand for information must exist. The information supplied should also be guided by principles of clarity and accuracy. ${ }^{20}$ Michener and Bersch argue that '...the most visible and inferable transparency is raw, verified, and

\footnotetext{
${ }^{15} \mathrm{D}$ Heald (2006b) 'Transparency as an Instrumental Value' in C Hood and Heald D (eds.), Transparency. The Key to Better Governance? 59-73.

16 A Fung., M Graham \& D Weil Full Disclosure: The Perils and Promise of Transparency (2007) Cambridge University Press.

${ }^{17} \mathrm{~B}$ Rawlins 'Give the emperor a mirror. Toward developing a stakeholder measurement of organizational transparency' (2009) 21 (1) Journal of Public Relations Research 75.

${ }^{18}$ Rawlins (note 17 above) 79.

${ }^{19}$ L Sproull and S Kiesler Connections: New Ways of Working in the Networked Organization MIT Press (1995) 117.

${ }^{20}$ Michener \& K Bersch (note 7 above) 19.
} 
simplified. ${ }^{21}$ This implies that the voluntary disclosure of information does not necessarily translate into effective transparent systems. According to Michener and Bersch, 'just because something is public does not mean it is visible. To be visible, information must reflect a high degree of completeness. Visibility also incorporates a second characteristic: the likelihood of finding information. ${ }^{22}$ The likelihood of finding information relates to the records management potential of various arbitration bodies and their recognition of the importance of this practice. The problem of lack of adequate record keeping may be present because of the culture where archival practices have little or no relevance since decisions are not informed by precedents. Records management are central to measuring the quality of transparency in any given system. Accessing records that are inaccurate or incomplete without the knowledge that some information might be missing or inaccurately recorded means that inaccurate conclusions will be drawn from such information.

Embedded within the idea of finding what the ideal transparent system should be is what has been termed the 'moral hazards' of transparency which is the 'possibility of manipulating the disclosure of information by the discloser which is informed by a motive to meddle with the inferability that can be drawn. ${ }^{23}$ According to Sproul and Kiesler,

other things equal, if groups send and receive accurate and complete information, they potentially compromise their strategic positions and threaten the balance of control in the organisation. Senders, knowing this, misrepresent information. Recipients, knowing this, discount information. Simply increasing the rate and scope of information sharing might only increase the number of misleading and discounted communications. ${ }^{24}$

In investment law, to avoid the moral hazards of transparency, the five core proposals for transparency by UNCTAD for ISDS are 'for a tribunal's decision/award be made public, public parties to enjoy unhindered access to the notice of arbitrationthe document that commences arbitration proceedings, public parties to have access to oral hearings, similar access to documents by all parties, and for interested parties to be

\footnotetext{
${ }^{21}$ Ibid 2.

22 Ibid 8.

${ }^{23}$ Ibid 11.

${ }^{24}$ L Sproull \& S Kiesler Connections: New Ways of Working in the Networked Organization (1995) 117.
} 
given an opportunity to comment. ${ }^{, 25}$ The recent 2013 UNCITRAL rules provide for mandatory disclosure and openness, participation by non-disputing parties and exceptions from the disclosure requirements. The United States adopted a model bilateral agreement in 2012, which provides for open hearings, submissions to be made public, pleadings be available to the public, and submissions by amicus curiae. The various improvements, adoptions and proposals for transparency within the arbitration system are discussed later in this article. Marian argued that procedural transparency ensures that three systemic goals are achieved which are 'securing the enforcement of the award, obtaining credibility for arbitral proceedings and minimising future risks through justification of the arbitral process. ${ }^{26}$

Transparency has been described as 'a moving target shaped by the interpretations, negotiations and enactments by legislators, regulators and other agendasetting stakeholders, in other words an arena of communication where ideals, expectations and demands are continuously formulated, enacted and contested. ${ }^{27}$ Though the values identified by Rawlins above are certainly relevant for the quality of information released, O’Neill believes such prescriptive approaches to transparency as a simple matter of information provision detaches information disclosure from communication and a mere act of transferring content from one person to another. ${ }^{28}$ This he believes discounts the importance of the reception and use of information, and of the process of communication. ${ }^{29}$

Viewed in the light of these sentiments by O'Neill, the important consideration in this article are the values that should guide the quality of information released and the process of release. Transparency in ISDS is viewed in the context of the voluntary supply of information by the arbitration tribunal which in some cases is subject to the consent of the parties or it is demanded by a party to advance an interest or by the public who believe the issue before the tribunal is of public interest. Relying on the qualities

\footnotetext{
${ }^{25} \mathrm{C}$ Marian 'Sustainable Investment through effective resolution of Investment disputes-Is transparency the answer?' 4 quoting International Institute for Sustainable Development and Center for International Environmental Law, Revising the UNCITRAL Arbitration Rules to Address Investor-state Arbitrations, Revised Version-December 2007, http://www.iisd.org/pdf/2008/investment_revising_uncitral_arbitration_dec.pdf .

${ }^{26}$ Marian (note 27 above) 9.

${ }^{27}$ M Flyverbom, L Christensen, H Hansen 'Disentangling the Power-Transparency Nexus' Paper prepared for the 1st Global Conference on Transparency Rutgers University, Newark, May 17-20 2011 12.

${ }^{28}$ O'Neill 'Transparency and the Ethics of Communication' in C Hood and D Heald (eds) Transparency: The Key to Better Governance? (2006) 81.

${ }^{29}$ Ibid.
} 
listed by Rawlins above, the following are relevant features for the quality of information disclosed to develop the ideal transparency standards:

Firstly, the accuracy and completeness of information should be ensured to make the available information devoid of manipulation to suit the purposes of the discloser of the information. Reliance on the information should lead to the user of such information being able to draw accurate conclusions from the information received. Secondly, the verifiability of the information should be possible if the accuracy of the information can be trusted. This is necessary for the optimal usefulness of the information to the recipient. Thirdly, easy accessibility of the information should be available which means inherent in transparency standards and implementation should be adequate records keeping and management, the development of appropriate rules of disclosure that will not unduly restrict the disclosure of public interest information. Fourthly, in terms of procedure, the release of the information should be affordable to the public and such information release should not be hindered by procedural constraints that will delay the release of the information as information delayed may in some cases be information denied.

These four features are necessary and must be present for the optimisation of transparency. If information is only accurate and complete without regard for the degree of accessibility and the timeliness of the release, then while such information is highly useful in terms of its quality, it does little to advance transparency. Where information is released timely and at an affordable rate without regard for the accuracy of the information released, the quality of information is low and the appearance of transparency is merely created.

Transparency is significant for public participation; hence, GAL justifies greater transparency. This is the argument advanced under GAL as it calls for public participation as a tool for accountability. To ensure such participation takes place, the presence of transparency needs to exist on three levels. These are transparency of the decision making process, transparency of the implementation and, transparency of the results. For ISDS, the need for transparency exists on different levels. At the initial stage of concluding treaties, transparency in the process is needed. The existing tradition has seen the conclusion of BITs by bureaucrats behind the scenes without the influence of public opinion or awareness by national law makers. For developing countries, traditionally, BITs have been treated as documents with no significant value to be 
signed by government leaders during state visits. This is changing however and transparency within the process of either concluding BITs or reviewing them are quickly becoming the norm rather than the exception in the face of increasing litigation against host states by investors on the basis of BITs. ${ }^{30}$ NAFTA, prior to the 2013 UNCITRAL rules, infused the most transparency into its process and the ICSID tribunal introduced amendments in 2006 which though introduced transparency procedures, still defers decisions on the release of awards and the submissions by the parties to the parties. ${ }^{31}$ The 2013 UNCITRAL has just undergone a review of its structures to make transparency the overriding principle in the execution of its functions. This is discussed in detail below.

At the arbitration stage, transparency can take different forms within the ISDS regime. It could mean the availability of information regarding substance and procedure. The tribunal in Suez and others $v$ Argentina held that 'public acceptance of the legitimacy of international arbitral processes, particularly when they involve states and matters of public interest, is strengthened by increased openness and increased knowledge as to how these processes function. ${ }^{32}$ The Organisation for Economic Cooperation and Development (OECD) Investment Committee agreed in June 2005 that 'there is a general understanding among the members of the Investment Committee that additional transparency, particularly, in relation to the publication of arbitral awards, subject to necessary safeguards for the protection of confidential business and governmental information, is desirable to enhance effectiveness and public acceptance of international investment arbitration., 33

The regime of international investment law is very fluid. There are numerous applicable investment treaties with similar principles in appearance but different in substance. Different arbitration systems have jurisdiction over these documents and they interpret these documents differently resulting in a vast range of jurisprudence. The ICSID and the UNCITRAL are the primary investment dispute bodies to be considered in this article because they handle the majority of BIT disputes. The next section

\footnotetext{
${ }^{30}$ South Africa, India, Columbia are some of the countries currently reviewing their BITs publicly.

${ }^{31}$ This is discussed in-depth in the next section below.

32 Suez and others $v$ Argentina, ICSID Case No ARB/03/19, Order in Response to a Petition for Transparency and Participation as Amicus Curiae, 19 May 2005, para. 22.

${ }^{33}$ International Investment Law: A Changing Landscape (Organization for Economic Cooperation and Development, 2005)10.
} 
evaluates the current state of transparency and confidentiality in ISDS, and the recent developments in promoting the transparency agenda.

\section{CURRENT STATE OF TRANSPARENCY IN ISDS}

In the amended UNCITRAL arbitration rules in 2010, article 34(5) provides that 'an award may be made public with the consent of all parties or where and to the extent disclosure is required of a party by legal duty, to protect or pursue a legal right or in relation to legal proceedings before a court or other competent authority.' This rule makes it possible for states to release awards that have been requested in terms of its freedom of information laws without violating the desires of private parties involved. This is consistent with Zoellner's concept of transparency discussed above relating to underlying obligations international law places on a state's internal legal regimes and procedures. The amended UNCITRAL rules allow the application of domestic laws without contravening international obligations.

The UNCITRAL rules were reviewed further in 2013 and the rules discussed below will be applicable from April 2014. Article 1 (3) (b) provides that

the arbitral tribunal shall have the power...to adapt the requirements of any specific provision...to the particular circumstances of the case, after consultation with the disputing parties, ... to conduct the arbitration in a practical manner and is consistent with the transparency objective of these Rules.

The articles goes further to grant discretion and authority to the tribunal and provides in article 1 (4)-(6) that in exercising discretion, the tribunal shall consider 'the public interest in transparency in treaty-based investor-State arbitration and in the particular arbitral proceedings; and the disputing parties' interest in a fair and efficient resolution of their dispute.' The rules do not preclude the exercise of other powers that promote transparency such as accepting submissions from third parties. Article 1 (7)-(8) also provides that the rules of transparency trump any other arbitration rules that may conflict with it though provisions of the treaty and any other law applicable to arbitration which disputing parties cannot derogate from trumps the transparency rules.

These articles establishes the default rule that for ISDS under investment treaties which are concluded after these rules come into effect and are to be resolved under UNCITRAL, the transparency rules will apply. They recognise the principle of the 
public interest, limit the ability of states to evade application of the rules; however, they preserve the superiority of the treaty rules. This is significant and discussed later.

Article 3 provides for mandatory and automatic disclosure of information, mandatory disclosure when a request is made and disclosure of documents through the discretion of the tribunal. ${ }^{34}$ Article 6 requires open hearings provided confidential information can be protected, the 'integrity of the arbitral processes' is protected and it does not affect logistics. ${ }^{35}$

Importantly, the disputing parties cannot veto open hearings. Despite the widely held claims regarding the confidential nature of arbitration systems, there were actually no explicit rules regarding confidentiality in arbitral rules until the recently introduced exceptions to transparency in the 2013 UNCITRAL rules. What these rules actually provide for in terms of privacy and confidentiality is considered below.

\subsection{Current state of Rules of Privacy and Confidentiality in ICSID and UNCITRAL}

ISDS is governed by contract principles which, from a business perspective, are crucial to the resolution of disputes. ${ }^{36}$ It has also been argued that the public also has a legitimate interest in investor protection and ISDS which will encourage cross-border investment by depoliticising state-party investment disputes. ${ }^{37}$

\footnotetext{
34 (1) Subject to article 7, the following documents shall be made available to the public: the notice of arbitration, the response to the notice of arbitration, the statement of claim, the statement of defence and any further written statements or written submissions by any disputing party; a table listing all exhibits to the aforesaid documents and to expert reports and witness statements, if such table has been prepared for the proceedings, but not the exhibits themselves; any written submissions by the non-disputing Party(ies) to the treaty and by third persons, transcripts of hearings, where available; and orders, decisions and awards of the arbitral tribunal. (2) Subject to article 7, expert reports and witness statements, exclusive of the exhibits thereto, shall be made available to the public, upon request by any person to the arbitral tribunal. (3) Subject to article 7, the arbitral tribunal may decide, on its own initiative or upon request from any person, and after consultation with the disputing parties, whether and how to make available exhibits and any other documents provided to, or issued by, the arbitral tribunal not falling within paragraphs 1 or 2 above. This may include, for example, making such documents available at a specified site.

35 (1.) Subject to article 6, paragraphs 2 and 3, hearings for the presentation of evidence or for oral argument ('hearings') shall be public. (2.) Where there is a need to protect confidential information or the integrity of the arbitral process pursuant to article 7, the arbitral tribunal shall make arrangements to hold in private that part of the hearing requiring such protection. (3.) The arbitral tribunal shall make logistical arrangements to facilitate the public access to hearings...

${ }^{36}$ A Norris \& K Metzidakis 'Public Protests, Private Contracts: Confidentiality in ICSID Arbitration and the Cochabamba Water War' (2010) 15 Harv Negot L Review 3150.

37 Norris \& Metzidakis (note 43 above) 52. See also Christina Knahr 'Transparency versus Confidentiality in International Investment Arbitration - The Biwater Gauff Compromise' 6 (2007) The Law and Practice of International Courts and Tribunals 97-118 110.
} 
In order to protect the intellectual property and trade secrets of investors which may be disclosed in arbitration proceedings, redacting or excluding certain information from public access is necessary. ${ }^{38}$ If the confidentiality of disclosures alongside the proprietary information of investors is guaranteed in arbitration proceedings, this may also encourage the disclosure of testimonies and evidence of witnesses which may otherwise not be provided if it will be subject to public scrutiny. ${ }^{39}$ Without public scrutiny however, the integrity of a witness's statement may be unchallenged with little or no opportunity, for those that can, to contradict the truthfulness of the disclosures. ${ }^{40}$

It has also been suggested that 'parties may have a legitimate interest in not wanting certain admissions or allegations disclosed to the public, or the loss of a case publicised, especially if the party is involved in other cases with similar claims and defences. ${ }^{41}$ Without confidentiality, parties may be unwilling to admit certain facts or negotiate towards settlement, especially in the case of states and their unwillingness to be seen or perceived to be negotiating away state sovereignty.

\subsubsection{ICSID Confidentiality Rules}

No provision in the ICSID Arbitration Rules expressly provides for the confidentiality of information submitted by the parties during the arbitration. The interpretation to the rules state that the parties are not prohibited from publishing their pleadings, but that they may agree not to do so. ${ }^{42}$ In Amco Asia Corp \& others $v$ The Republic of Indonesia, the tribunal rejected the request to prevent publication of the case on the ground that 'neither the ICSID Convention nor the rules nor any accepted principle of confidentiality in arbitration prevented a party from revealing information about an arbitration case to the newspapers. ${ }^{43}$

\subsubsection{ICSID Additional Facility Rules}

These rules also do not contain any duty of confidentiality but affords privacy protections such as the limitation of attendance at hearings in article 39. Article 44 also limits publication of minutes of hearings. In Metalclad v United States, the tribunal held that

\footnotetext{
${ }^{38}$ Norris \& Metzidakis (note 38 above) 53.

${ }^{39}$ Ibid56.

${ }^{40}$ Ibid.

${ }^{41}$ Ibid 57.

${ }^{42}$ Rule 30.

43 (1983) 1 ICSID Reports 410, 412.
} 
there remains a question as to whether there exists any general principle of confidentiality that would operate to prohibit public discussion of the arbitration proceedings by either party. Neither the NAFTA nor the ICSID (additional facility) rules contain any express restriction on the freedom of the parties in this respect, unless the agreement between the parties incorporates such a limitation; each of them is free to speak publicly of the arbitration. It may be observed that no such limitation is written into such major arbitral texts as the UNCITRAL Rules or the draft articles on arbitration adopted by the International Law Commission. $^{44}$

\subsubsection{UNCITRAL Confidentiality Rules}

Article 25(4) of the UNCITRAL rules provides that 'hearings are to be held in camera unless the parties agree otherwise.' No other provisions in the UNCITRAL rules expressly impose a general duty of confidentiality. In SD Myers Inc v Canada, the tribunal held that 'it has not been established that any general principle of confidentiality exists in arbitration such as that currently before this tribunal... ${ }^{45}$ In terms of article 7 of the 2013 UNCITRAL rules, extensive rules of confidentiality are introduced which identifies what constitutes confidential information, how to prevent confidential information from being made available to the public and in cases where the tribunal rules that a document can be made available to the public, it does not prevent a party that voluntarily introduced the document into the tribunals records from withdrawing it. ${ }^{46}$

\footnotetext{
${ }^{44}$ Case No ARB(AF)/97/1 para 13.

${ }^{45}$ Procedural Order No 16 of 13 May 2000 para 8.

${ }^{46}$ Article 7 provides that 'confidential or protected information consists of (a) confidential business information; (b) information that is protected against being made available to the public under the treaty; (c) information that is protected against being made available to the public, in the case of the information of the respondent, under the law of the respondent, and in the case of other information, under any law or rules determined by the arbitral tribunal to be applicable to the disclosure of such information; or (d) information the disclosure of which would impede law enforcement. (3.) The arbitral tribunal, after consultation with the disputing parties, shall make arrangements to prevent any confidential or protected information from being made available to the public including by putting in place, as appropriate: (a) time limits in which a disputing party, non-disputing Party to the treaty, or third person shall give notice that it seeks protection for such information in documents; (b) procedures for the prompt designation and redaction of the particular confidential or protected information in such documents; and (c) procedures for holding hearings in private to the extent required by article 6, paragraph 2 . Any determination as to whether information is confidential or protected shall be made by the arbitral tribunal after consultation with the disputing parties. (4.) Where the arbitral tribunal determines that information should not be redacted from a document, or that a document should not be prevented from being made available to the public, any disputing party, non-disputing Party to the treaty or third person that voluntarily introduced
} 
These rules allow the redaction of confidential information in documents that are subject to the exceptions and prevent the blanket refusal of information subject to the exceptions. Importantly, these exceptions defer to the applicable confidential rules of the treaty or the domestic rules of a state. Treaty rules must therefore not be unduly restrictive if the approach through which transparency of ISDS can be achieved in UNCITRAL will be realised. States in negotiating their treaties would have to include provisions directly in their investment treaties, making transparency obligatory.

Transparency can be introduced in two ways. It can be introduced as a requirement in the investment treaty on which the arbitration is based and it can also be introduced into the arbitration rules. Both mechanisms have been used by states in order to promote transparency in the ISDS process. I advocate the former position to avoid and override many problems that may be encountered in the current arbitration rules or the applicability of any future amendments. In addition, by introducing transparency norm in the treaty itself, there is a greater opportunity for public participation. Introducing transparency provisions in the drafting of investment treaties will be a significant development. It will also overcome the ability of states to bypass the newly developed UNCITRAL rules where the treaty rules prevail over the application of the transparency rules. Reliance will no longer be placed on arbitration rules as the only applicable rules for transparency in dispute resolution. An example of this is the NAFTA rule that allowed the publication of awards where the dispute is between the USA and Canada by the parties without the consent of the other party, a clear contrast to the UNCITRAL rules prior to its 2013 amendment. ${ }^{47}$

The NAFTA Free Trade Commission issued an interpretation of chapter 11 dealing with dispute settlement that 'nothing in the NAFTA imposes a general duty of confidentiality on the disputing parties to Chapter Eleven arbitration.' It also allows documents submitted to the tribunal to be publicly released but allows a redaction of confidential information, or information protected from disclosure under the party's domestic law or which must be withheld in compliance with relevant applicable arbitral rules. This interpretation gives unilateral powers to parties in the disclosure of documents.

the document into the record shall be permitted to withdraw all or part of the document from the record of the arbitral proceedings.

${ }^{47}$ Article 1137. 
Another example is the 2004 Central America Free Trade Agreement (CAFTADR) between the United States, the Dominican Republic, Costa Rica, El Salvador, Guatemala, Nicaragua and Honduras. Article 10.21 of the CAFTA-DR deals with transparency and the exchange of documents between parties and the circumstances under which redacted versions can be made available to the public. ${ }^{48}$ Sub-section 5 specifically provides that 'nothing in this section requires a respondent to withhold from the public information required to be disclosed by its laws.'

The CAFTA-DR agreement recognises the need to balance domestic and international law, hence the need for sub-section 5. It also means that the decision of a tribunal is not final and binding as the laws and court decisions of a state can overrule the decision of a tribunal. The CAFTA-DR provides that a disputing party must identify a particular reason why information must be restricted and there remains an obligation to publish a redacted version of that information.

48 "1. Subject to paragraphs 2 and 4, the respondent shall, after receiving the following documents, promptly transmit them to the non-disputing Parties and make them available to the public:

(a) the notice of intent;

(b) the notice of arbitration;

(c) pleadings, memorials, and briefs submitted to the tribunal by a disputing party and any written submissions submitted pursuant to Article 10.20.2 and 10.20.3 and Article 10.25;

(d) minutes or transcripts of hearings of the tribunal, where available; and

(e) orders, awards, and decisions of the tribunal.

3. Nothing in this Section requires a respondent to disclose protected information or to furnish or allow access to information that it may withhold in accordance with Article 21.2 (Essential Security) or Article 21.5 (Disclosure of Information).

4. Any protected information that is submitted to the tribunal shall be protected from disclosure in accordance with the following procedures:

(a) Subject to subparagraph (d), neither the disputing parties nor the tribunal shall disclose to any nondisputing Party or to the public any protected information where the disputing party that provided the information clearly designates it in accordance with subparagraph (b);

(b) Any disputing party claiming that certain information constitutes protected information shall clearly designate the information at the time it is submitted to the tribunal;

(c) A disputing party shall, at the same time that it submits a document containing information claimed to be protected information, submit a redacted version of the document that does not contain the information. Only the redacted version shall be provided to the non-disputing Parties and made public in accordance with paragraph 1 ; and

(d) The tribunal shall decide any objection regarding the designation of information claimed to be protected information. If the tribunal determines that such information was not properly designated, the disputing party that submitted the information may

(i) Withdraw all or part of its submission containing such information, or (ii) agree to resubmit complete and redacted documents with corrected designations in accordance with the tribunal's determination and subparagraph (c). In either case, the other disputing party shall, whenever necessary, resubmit complete and redacted documents which either remove the information withdrawn under (i) by the disputing party that first submitted the information or re-designate the information consistent with the designation under (ii) of the disputing party that first submitted the information. 
The CAFTA-DR also allows public hearings. ${ }^{49}$ This provision recognises the need to balance transparency against confidentiality and despite the provisions of investment treaties, tribunals are central to achieving this balance and giving effect to the intention of the treaty parties. ${ }^{50}$

Emerging model BITs have also incorporated rules of access to information that recognise the shift towards transparency norms in the investment legal system. In the Southern African Development Community (SADC) model BIT, provision is made for the disclosure of information in three tiers. Firstly, article 12 provides for the disclosure of information by the investor to the host state concerning the investment and recognises the right of the host state to receive timely and accurate information. ${ }^{51}$ Secondly, the provision goes further to recognise the right of the host state to disclose such information to the public in accordance with its domestic law. In the commentary to article $18^{52}$ which provides that investment contracts and payments must also be made available to the public, it is stated that,

\footnotetext{
49 Article 10.21 provides that 'the tribunal shall conduct hearings open to the public and shall determine, in consultation with the disputing parties, the appropriate logistical arrangements. However, any disputing party that intends to use information designated as protected information in a hearing shall so advise the tribunal. The tribunal shall make appropriate arrangements to protect the information from disclosure.' The Commerce Group Corporation and San Sebastian Gold Mines v El Salvador was opened to the public based on this provision.

50 J Harrison 'Recent Developments to Promote Transparency and Public Participation in InvestmentTreaty Arbitration' University of Edinburgh School of Law Working Paper Series No 2011/01 14.

51 12.1. An Investor shall provide such information to an actual or potential Host State as that State Party may require concerning the Investment in question and the corporate history and practices of the Investor, for purposes of decision making in relation to that Investment or solely for statistical purposes.

12.2. The actual or potential Host State shall have the right to timely and accurate information in this regard. An Investor shall not commit fraud or provide false or misleading information provided in accordance with this Article.

12.3. A material breach of paragraph 12.2 by an Investor or an Investment is deemed to constitute a breach of the domestic law of the Host State concerning the establishment, acquisition, management, operation and disposition of Investments.

12.4. The actual or potential Host State Party may make such information available to the public in the location where the Investment is to be located, subject to other applicable law and the redaction of confidential business information. The State Party shall protect any confidential business information from any disclosure that would prejudice the competitive position of the Investor or the Investment.

12.5. Nothing in this Article shall be construed to prevent a State Party from otherwise obtaining or disclosing information in connection with the equitable and good faith application of its domestic law or in connection with disputes between the Investor and the State regarding the Investment.

52 18.2. Investors or their investments shall make public in a timely manner all payments made to a government related to the establishment or right to operate of an Investment, including all taxes, royalties and similar payments.

18.3. Where feasible, such contracts and payments shall be made available on an Internet website freely accessible by the public.

18.4. The State Party that is the recipient of payments or party to an investment-related contract shall [have the right to] make the payments and contracts available to the public, including through an Internet site freely accessible to the public.
} 
there is a growing concern for transparency in contract negotiation that many developing countries and international organizations are now responding to. Indeed, many now see this as one of the most important ingredients in the fight against corruption. This article sets out the principle of transparency and an expectation that both investors and governments will act on this expectation.

Thirdly, the model BIT provides in article 24 that state parties shall make available to an investor, all laws and regulations including policies and administrative guidelines that may affect the investments of investors. ${ }^{53}$

If the approach suggested in this section is followed, it will address the question of obligations international law places on a state's internal legal regimes and procedures and the relations between institutions and regimes of international law and member states mentioned earlier. A state party will be in the position to establish the supremacy of its internal access to information laws in these disputes and ensure that no conflict of interest arises when a state is obliged to release information to the public and also comply with a confidentiality order of a tribunal.

In South Africa, where there is a constitutional guarantee of the right of access to information, the model in the NAFTA and CAFTA-DR agreements that allows access to information based on the domestic laws of a state will allow a treaty party to ensure the protection and enforcement of constitutional rights when negotiating treaties and infuse transparency into the arbitration process. The problem still remains that civil society participation hardly exists when BITs are being negotiated though this trend is currently changing with countries like South Africa publicly reviewing their BIT regime with public participation. This deficit within the current model of transparency where a balancing of interests exists necessitates the need to justify transparency on the grounds

18.5. Confidential business information shall be redacted from contracts made public in accordance with this Article.

53 24.1. Each State Party shall promptly publish, or otherwise make publicly available, its laws and regulations of general application as well as international agreements that may affect the Investments of Investors of the other State Party.

24.2. Each State Party shall endeavour to promptly publish, or otherwise make publicly available, its policies and administrative guidelines or procedures that may affect investment under this Agreement. 
of GAL which creates the opportunity for further advances for the improvement of transparency mechanisms.

\section{NEGOTIATING TRANSPARENCY FOR ISDS: APPLYING GAL}

Magraw and Amerasinghe in 'Transparency and Public Participation in Investor-State Arbitration' start by discussing the power shifts in investor-state arbitration relevant to transparency and public participation. ${ }^{54}$ They state that investment protection laws have shifted power from the state to investors and secondly, they argue that power has shifted from the public to the state because there has been a decrease in holding states accountable to citizens due to the use of the traditionally non-transparent arbitration tribunals. ${ }^{55}$

Transparency increases the quality of decision making because in instances where awards are published for public scrutiny, there is a greater pressure on arbitrators to write well-reasoned decisions. ${ }^{56}$ The public scrutiny of the arbitration process also decreases the likelihood of corruption by parties. In the Piero Foresti case, there was a reported allegation of a demand for bribery by a government representative of South Africa and this fact would likely not have been known without the transparency of the process. ${ }^{57}$ Given the fact that access to information is an entrenched principle in most democratic states that allows for the realisation of other rights as is often theorised by freedom of information experts, transparency within ISDS also allows the realisation of other rights such as access to justice. The notion of access to justice here is conceptualised as the right of every individual to require the state to provide a means of dispute resolution that is equally accessible and socially just. ${ }^{58}$ This goes to substance and form and in the context of ISDS, relates to the right to public participation in proceedings that have a significant public interest impact. Such participation should take into account administrative law such as principles of fairness, open hearings, and right to be heard. This is closely connected to the protection of interests of the public who are often not aware of their interests within an arbitration dispute and how to

\footnotetext{
54 D Magraw \& N Amerasinghe in 'Transparency and Public Participation in Investor-State Arbitration' (2008) 15 ILSA J Int \& Comparative Law 337.

${ }_{55}$ Magraw \& Amerasinghe (note 54 above) 3.

56 Ibid 6.

${ }^{57}$ Case No ARB(AF)/07/1 para 31

${ }^{58}$ Cappelletti M and Garth R'Access to Justice: The Worldwide Movement to Make Rights Effective, A General Report' in Mauro Cappelletti and Robert Garth (eds) Access to Justice: A World SurveyVol 1 (1978) Milan, Dott. A Guiffre Editore at 6 quoted in F Adeleke 'Access to Justice and Freedom of Information: The Case of South Africa' (2012) 1 African Journal of Clinical Legal Education and Access to Justice 108
} 
protect them. By opening up the arbitral process, the likelihood of increasing the consistency and coherence in interpretation of law in similar cases will enhance certainty within the system and the anticipation of likely outcomes of cases preventing the need to litigate every case. ${ }^{59}$

Lack of transparency may also harm the legitimacy and credibility of the dispute resolution bodies, such as limiting scrutiny of government decisions by the public and the cover up of abuse and corruption by investors and government officials. ${ }^{60}$ Transparency facilitates the accountability of parties in the dispute settlement process and as a result, compliance and implementation of ISDS decisions by parties may be more effective. ${ }^{61}$

Despite the advantages of transparency, there are disadvantages as well. Costs of tribunal may increase with the implementation of transparency reforms. The reforms may cause delay of the arbitration process, impair the necessity for confidentiality which may impair the procedural integrity of the arbitration system among private investors. ${ }^{62}$ However, the considerations for transparency are nevertheless greater than the costs of confidentiality and of utmost importance is the balance of these two considerations. Different forms of imputing transparency into ISDS can be achieved under the GAL framework as discussed below.

If the objective of transparency is to be achieved within ISDS, imputing common ideals that safeguard the legitimacy of the judicial systems of domestic jurisdictions is perhaps necessary. Reasons for this include access to justice by the parties, how to access information from those who hold it and the basis on which such access to information can be made. GAL principles such as error of law, procedural fairness and audi alteram partem ${ }^{63}$ all play a role in ensuring the legitimacy of the arbitration system. Some of these principles currently apply in the rules of the ICSID that address the procedural fairness of the proceedings, independence and impartiality of the arbitrators and written reasons for decisions handed down. ISDS is one of the best examples of GAL. ISDS should be guided by rules of public law adjudication and the powers conferred on arbitration tribunals through BITs are no more than delegated

\footnotetext{
${ }^{59}$ D Magraw \& N Amerasinghe (note 54 above) 9.

${ }^{60}$ Ibid.

${ }^{61}$ Ibid.

62 Ibid 10-11.

${ }^{63}$ Right to be heard.
} 
authority from the treaty parties. Hoexter defines administrative law as the regulation of activities of bodies that exercise public powers or performs public functions, irrespective of whether those bodies are public authorities in a strict sense. ${ }^{64}$ Administrative acts can be legislative or adjudicative and in the context of ISDS, the act is adjudicative. Adjudicative judicial administrative acts concern the resolution of disputes by an authority. These bodies are in most cases specialised and more interventionist than courts; their decisions have prospective effect and bind large administrative hierarchies; they are not dogged by cumbersome procedural rules of courts and the doctrine of precedent and are consequently more flexible and can operate at a greater speed. ${ }^{65}$ To determine whether an act is administrative, the factors considered include the nature of the power, the source of the power, its subject matter, whether it involves the performance of a public duty, how closely it involves the implementation of legislation or the making of policy in the broad sense. ${ }^{66}$

Applying these factors, there can be little doubt that ISDS tribunals exercise the substantive and procedural power delegated to them from the states that concluded the BIT under which the applicable dispute arose. Since the nature of the power is delegated, the source comes from sovereign states. The subject matter can be of a public nature although it reflects a state descending into the commercial arena but the performance is adjudicative which is a public duty and closely involves the implementation of a treaty and pronouncing on the policy of a state. There are five substantive principles of GAL that are necessary for consideration in advancing this argument.

The principle of lawfulness requires that the administrative authorities should base their decisions in law and the content should comply with the law. ${ }^{67}$ It also requires that the functions and powers of administrative authorities should be validly enacted and sufficiently clear and specific. ${ }^{68}$ Among the general principles of lawfulness is that nobody may at the same time be judge and party in a dispute. ${ }^{69}$ ISDS tribunals can only maintain their legitimacy and procedural integrity if as stated earlier, awards are published and decisions can be seen to be based in sound legal reasoning. The disparity

\footnotetext{
${ }^{64}$ C Hoexter, Administrative Law in South Africa (2007) 2.

${ }^{65}$ Ibid 52.

${ }^{66}$ Ibid 4.

${ }^{67}$ Council of Europe, Project on Administrative Law Principles of Administrative Law concerning the relations between administrative authorities and private persons: A handbook (1996) 13.

${ }^{68}$ Ibid.

${ }^{69}$ Council of Europe (note 67 above) 14.
} 
in the reasoning in the cases of $L G \& E$ and $C M S \vee$ Argentina where two tribunals reached different conclusions on similar sets of facts and regarding the same issue of law reflects the need for the lawfulness principle to guide arbitration decisions.

The principle of equality before the law requires that where cases are objectively the same, their treatment must be the same. ${ }^{70}$ This is no indication that each case will not be individually subject to applicable laws and rules. This approach allows a reasonable form of foreseeability to the outcome of cases and protects the outcome of cases from arbitrary or irrational decisions. ${ }^{71}$ Such decisions should also be guided by the administrative principles of rationality and proportionality. This would involve a fair balance between public and private interests. ${ }^{72}$

Conformity with the aim of BITs ensures that ISDS tribunals exercise their powers solely for the purposes for which they exist and do not step outside the delegated authority. This is in line with the common law principle of ultra vires. ${ }^{73}$ To ensure that this conformity exists, the principle of objectivity and impartiality by arbitrators is also a relevant consideration and rules guiding the promotion of these principles must be enacted.

The principle of nemo iudex in sua causa is the rule against bias based on two common law principles of good administration. Firstly, decisions are more likely to be sound when the decision-maker is unbiased. Secondly, the public will have more faith in the administrative process when justice is not only done but seen to be done. ${ }^{74}$ At common law, there are two different tests. The first requires a real likelihood of bias, the other a reasonable suspicion. The test of reasonable suspicion would be the preferred option, so, in order to have a decision set aside; the affected individual merely had to prove an appearance of partiality rather than its actual existence. ${ }^{75}$ Bias can relate to instances where a financial interest, personal interest, or where feelings of substantial prejudice, bias on the subject matter played a role. ${ }^{76}$ In ISDS where the parties appoint their preferred arbitrator, this administrative principle is perhaps the most relevant administrative principle.

\footnotetext{
70 Ibid

${ }^{71}$ Ibid 15.

${ }^{72}$ Ibid 16.

73 Ibid.

${ }^{74}$ Hoexter (note 64 above) 405.

${ }^{75}$ Ibid.

${ }^{76}$ Ibid 407-410.
} 
The principle of audi alteram partem may also be applicable here. Procedural fairness in the form of audi alteram partem is concerned with giving people an opportunity to participate in the decisions that will affect them and a chance of influencing the outcome of those decisions. ${ }^{77}$ Such participation is a safeguard that signals respect for the dignity and worth of the participants and also improves the quality and rationality of administrative decision making to enhance its legitimacy. ${ }^{78}$ In ISDS, this principle must be extended to the public participation of non-disputing parties whose interests are affected in the arbitration.

The UNCTAD in 2013 released a report on transparency in international investment agreements which sought to examine 'the way in which traditional transparency issues have been addressed in international investment agreements since 2004, the emergence of investor responsibilities as a consideration within transparency issues, and the introduction of a transparency dimension into investor-State dispute settlement. ${ }^{, 79}$ The report sought to address the transparency imperatives from a sustainable development perspective and through a consideration of some of the existing good practices in various investment agreements, made recommendations for future investment instruments. ${ }^{80}$

The report recognised the emergence of transparency in ISDS as a result of the increasing emphasis on the public interest inherent within investor-state disputes which involves public service sectors, the possible involvement of broader human rights concerns, the determination of large damages awarded against host states which are funded by public money, the presence of a state in the arbitration which triggers good governance obligations, the threat of arbitration from an investor having a 'chilling' effect on government policy and the growing appreciation of the impact of procedural matters in ISDS. ${ }^{81}$ Another central concern is how lack of sufficient access to information of arbitration claims and disputes can affect sustainable development objectives. $^{82}$

\footnotetext{
77 Ibid 326.

${ }^{78}$ Ibid 326-327.

${ }^{79}$ UNCTAD Series on Issues in International Investment Agreements II 'Transparency' United Nations 2012, pg xi.

${ }^{80}$ Ibid.

${ }^{81}$ Ibid 36.

${ }^{82}$ Ibid.
} 
The UNCTAD report considers transparency from three perspectives. The first is what it called state-centred transparency obligations which include a binding obligation to make certain information public, a soft obligation to cooperate and consult with the other contracting party, a binding obligation to pro-actively exchange information with the other contracting party, and a binding obligation to respond to information requests. ${ }^{83}$ The second deals with investor responsibilities regarding the obligation to comply with laws and regulations, the authority of the host state to collect information from the investor and the duty on the investor to cooperate with the state. ${ }^{84}$ The third perspective deals with transparency in the ISDS itself in relation to access to information and amicus participation. ${ }^{85}$ Recognising that rules of institutions like the ICSID and UNCITRAL are being revised to increase transparency and amicus participation, the UNCTAD report linked these issues with the fair and equitable treatment standard of investment agreements, corporate social responsibility and GAL. ${ }^{86}$

On fair and equitable treatment, based on the opinion of the tribunal in Tecmed $v$ Mexico, the report associates transparency to the equitable treatment standard. ${ }^{87}$ Relying on the decision of Frontier Petroleum v Czech Republic, the report also suggests that an investor's legitimate expectations are related to transparency. ${ }^{88}$ The UNCTAD report also recognises the increasing trend in arbitration tribunals to use the preambles of investment agreements in interpretation. The reports states that given the reference to social responsibility practices in the preambles, this point to the expectation of states that foreign investors should be willing to engage in more sustainability reporting which will assist host states in maintaining on-going investor transparency throughout project

\footnotetext{
${ }^{83}$ Ibid 25.

${ }^{84}$ Ibid 30-35.

${ }^{85}$ Ibid 37-42.

${ }^{86}$ Ibid 51.

87 'The Arbitral Tribunal considers that this provision [embodying the FET standard] of the Agreement, in light of the good faith principle established by international law, requires the Contracting Parties to provide to international investments treatment that does not affect the basic expectations that were taken into account by the foreign investor to make the investment. The foreign investor expects the host State to act in a consistent manner, free from ambiguity and totally transparently in its relations with the foreign investor, so that it may know beforehand any and all rules and regulations that will govern its investments, as well as the goals of the relevant policies and administrative practices or directives, to be able to plan its investment and comply with such regulations.' Tecnicas Medioambientales Tecmed, SA $v$ United Mexican States ICSID Case No ARB (AF)/00/2, Award, 29 May 2003, para 154.

88 'The protection of the investor's legitimate expectations is closely related to the concepts of transparency and stability. Transparency means that the legal framework for the investor's operations is readily apparent.' Frontier Petroleum Services Ltd v Czech Republic, PCA-UNCITRAL Arbitration Rules, Final Award, 12 November 2010, para 285.
} 
implementation. ${ }^{89}$ The UNCTAD report also recognises the fact that GAL is concerned with principles of transparency, public participation, and due process, but argues that "the application of the "global administrative law" label could potentially impede transparency reforms...as it is arguably harder to criticise a system once it has been framed as the embodiment of the rule of law., 90

It is difficult to understand why a reference to transparency as part of the rule of law will affect transparency reforms as the report suggests. As argued earlier, existing ISDS awards already recognise the importance of administrative law principles such as good faith, reasonableness, due process of law, non-discrimination, transparency as well as the public purpose and policy powers of states to introduce measures that affect public interests. The argument for the application of GAL is to deal with the application of transparency norms in a holistic and coordinated form that encourages arbitrators to apply GAL principles to improve the system and does not preclude the possibility of criticising or improving the system where a deficit still exists. The definition of GAL includes the opportunity for a review of decisions that are made which currently does not exist in ISDS. By suggesting that GAL principles should be applied by the system, the adoption of these rules are not recommended to be applied in a rigid and formalistic way that will not allow for future reforms that will further advance transparency. One of the outcomes of GAL is the right to appeal to another authority for the review of decisions. Where the opportunity for the comprehensive reform of the arbitration system arises in the future, the adoption of this outcome is welcome.

The UNCTAD report suggests a number of provisions that can be introduced into investment agreements that can bolster transparency. In recommending the increased availability of documents and information, access to oral hearings and amicus submissions, the report recognises the arguments against these measures which include increased cost to the disputing parties, the greater administrative burden and the potential for confidential information to be compromised. ${ }^{91}$ The report recommends various formulations for future incorporation which I support because it recognises the principle of public participation that I promote in this article and sets out minimum sets of documents that constitute a binding obligation on the parties and the tribunal to release to the public. The transparency approach adopted by the UNCTAD is developed

\footnotetext{
${ }^{89}$ UNCTAD report (note 79 above) 55.

${ }^{90}$ Ibid 56.

${ }^{91}$ UNCTAD (note 79 above) 75.
} 
from a perspective where there is an acknowledgement that investment disputes and the issues arising affect the development of states and a more holistic approach is needed to accommodate other competing interests without unfairly prejudicing the parties, particularly, the investors. The report's recommendations include making available documents relating to the notice of intent, the notice of arbitration, pleadings, memorials, and briefs submitted to the tribunal by a disputing party and any written submissions by non-disputing parties, minutes or transcripts of hearings of the tribunal, where available and orders, awards, and decisions of the tribunal. For access to oral hearings, it is recommended that the hearings of the tribunal should be open to the public with the tribunal making appropriate arrangements to protect any confidential information from disclosure during the open hearing.

Where BITs contain detailed provisions to govern arbitration alongside mechanisms for access to information, public participation and amicus submissions such as the above, this provides a guiding rule for arbitrators to convene arbitration and ensure public participation and transparency of the process.

\section{CONCLUSION}

For transparency, there are areas in the domestic law of states that have direct implications for BITs and ISDS. For example, the recognition of the right to access information as a human right is significant for ISDS given the private nature of ISDS that excludes certain transparency norms. ${ }^{92}$ Despite the pessimistic portrayal of the lack of transparency within the investment regime in the discourse of the current ISDS rules in this article, there are certain areas which can largely be regarded as transparent in terms of the knowledge and information disclosure surrounding them. These areas include the applicable rules that guide the arbitration procedure and the content of BITs to the extent that they are publicly available. This is an important aspect of the GAL approach. There are however other forms of information and knowledge that should be freely available but are not. ${ }^{93}$ These include the fact that not all BITs in existence are

\footnotetext{
92 The right of access to information has attained universal recognition with several regional human rights treaties upholding the recognition of this right as well as regional courts such as the Inter-American and the European Courts recognising this right as well as its linkage to other rights. Claude Reyes $v$ Chile, Inter-American Court of Human Rights IACHR Series C no 151 para 84-85.

${ }^{93}$ See J A Maupin 'Transparency in International Investment Law: The Good, the Bad, and the Murky' in Andrea Bianchi \& Anne Peters (eds) Transparency in International Law (Cambridge University Press 2013).
} 
known and the magnitude of the regime cannot be fully determined. ${ }^{94}$ Also, just as the number of BITs is unknown, so also are the number of arbitration disputes and the resulting awards since not all dispute resolution bodies are obliged to disclose the existence of all disputes before them. ${ }^{95}$ For the disputes that are in the public domain, not all information pertaining to the disputes is currently disclosed. ${ }^{96}$

It is obvious that not all information can be made freely available upon demand. Legitimate commercial interests of investors and certain state information are usual exemptions to public information disclosure. ${ }^{97}$ Consistent with the argument in this paper for a hybrid application of domestic and international law in ISDS, the right of access information is now firmly embedded as a human right including in South Africa with domestic legislation giving effect to this right. Therefore, ISDS tribunals should begin to recognise that the principle of confidentiality should no longer be treated as an absolute rule and disclosures should not be left to the discretion of the parties. South Africa's access to information law recognises confidentiality of commercial information as well as a duty to protect confidentiality owed to a party in terms of an agreement such as in BITs as an exemption to disclosure of information. ${ }^{98}$ However, section 46 of the law also recognises the mandatory disclosure of information in the public interest regardless of any exemptions in the law particularly where the public interest in disclosure outweighs the harm contemplated in the exemptions to disclosure. ${ }^{99}$ This suggests that under South African law, aside from the recognition of access to information as a human right, rules of confidentiality are not regarded as absolute where public interest matters apply.

In a 2012 judgment by the Polish Administrative Court, the court held that arbitral awards under investment treaties constitute public information and are eligible for release under Poland's freedom of information law. ${ }^{100}$ A local NGO had applied for

\footnotetext{
94 Ibid.

${ }^{95}$ Ibid.

${ }^{96}$ See the discussion on the Vattenfall v Germany case discussed above.

${ }^{97}$ For instance, this might include information on national security contracts.

${ }^{98}$ Sections 36 and 37 of the Promotion of Access to Information Act 2 of 2000.

${ }^{99}$ Promotion of Access to Information Act 2 of 2000.

100 J Hepburn \& F Balcerzak 'Polish Court rules on release of investment arbitration awards under Freedom of Information Law' Investment Arbitration Reporter (January 2013) <www.iareporter.com/articles/20130102 3 >; The recent decision in EURAM v The Slovak Republic was only publicly released due to a request under Slovakia's Freedom of Information Law. See J Hepburn 'Arbitrators interpret BIT arbitration clause narrowly, and point to Australia as example of state not viewing investor-state arbitration as essential to investment protection' Investment Arbitration Reporter (April 2015) <http://www.iareporter.com/articles/arbitrators-interpret-bit-arbitration-clause-narrowly-
} 
a yet-to-be-published investment treaty award relating to the Servier v Poland case. The government had raised Article 32.5 of the UNCITRAL rules to prevent disclosure of the award which provided that awards can only be released subject to the consent of the parties. ${ }^{101}$ The court held, however, that the award was public information and the respondent who had received the information request was a public authority bound by the freedom of information law. ${ }^{102}$

The parties themselves benefit from the transparency of certain areas to aid their cases. Where awards are published and interpretation of substantive principles are subject to scrutiny, disputing parties can benefit from ways on how they should approach their particular dispute and anticipate the outcomes of disputes. As a result, as a starting point, disputing parties should not unduly withhold their consent where necessary in disclosing information regarding their dispute.

The principles that I suggest here help to refine GAL and extend its application further in international investment law. If the substantive principles proposed are adopted, this would significantly improve the legitimacy of ISDS.

and-point-to-australia-as-example-of-state-not-viewing-investor-state-arbitration-as-essential-toinvestment-protection/>

${ }^{101}$ Ibid.

102 Ibid. 